\title{
Atividade antifúngica de óleos essenciais sobre Candida sp. isolada do útero de égua
}

Guilherme Novello ${ }^{[]^{*}}$, Gabriel Victoria Martins ${ }^{[a]}$, Raqueli Teresinha França ${ }^{\left[{ }^{[a]}\right.}$, Rafael dos Santos Bandeira ${ }^{[b]}$, Gabriel Fernandes Pauletti ${ }^{[a]}$, Ana Paula Longaray Delamare ${ }^{[a]}$, Fernando Paixão Lisboa ${ }^{[a]}$

[a] Universidade de Caxias do Sul (UCS), São Marcos, RS, Brasil

[b] Universidade Estadual Paulista (UNESP), Botucatu, SP, Brasil

*Autor correspondente

e-mail: guiganovello@hotmail.com

\section{Resumo}

A endometrite é a principal causa de infertilidade em éguas e é causada principalmente por bactérias e fungos. Os fungos são microrganismos oportunistas, e os fatores predisponentes para seu desenvolvimento são queda da imunidade, desequilíbrio da flora vaginal pelo uso indiscriminado de antibióticos e má conformação vulvar. Devido a isso, é comum que a endometrite fúngica tenha caráter crônico. Os principais agentes causadores de endometrite fúngica são Aspergillus sp. e Candida sp. Os tratamentos incluem lavagens uterinas, infusão de substâncias antissépticas, administração oral e intrauterina de agentes antifúngicos, entre outros. No entanto, é importante isolar o agente causador e realizar testes de sensibilidade específicos. 0 objetivo deste trabalho é testar o efeito antifúngico in vitro de óleos essenciais como alternativa de tratamento para uma endometrite fúngica, o qual não obteve sucesso em tratamento convencional in vivo. Foram obtidos óleos essenciais de Alecrim (Rosmarinus officinalis) e Capim Cidreira (Cymbopogon citratus) através do método de extração por hidrodestilação por aparelho tipo Clevenger, por uma hora ( $100 \mathrm{~g}$ de plantas desidratadas). 0 fungo foi isolado do útero de uma égua da raça Crioula, com 24 anos e histórico de 8 anos de infertilidade. Para o isolamento, foi colhido swab uterino durante o estro com coletor Provar $^{\circledR}$ e a amostra obtida foi acondicionada em meio de transporte Stuart, sendo enviada ao laboratório ainda no mesmo dia. A citologia foi realizada com coletor citológico Provar ${ }^{\circledR}$, e o esfregaço fixado e corado com Panótipo Rápido ${ }^{\circledR}$. Na avaliação citológica foi constatada uma quantidade expressiva de leveduras, não sendo observada a presença de hifas. Na avaliação microbiológica, observou-se crescimento significativo de Candida sp. após 48 horas de incubação, não havendo crescimento bacteriano concomitante. Após a confirmação do diagnóstico, foi instituído tratamento com aplicação oral de $1 \mathrm{~g}$ de fluconazol SID, iniciando no meio do estro até o dia da colheita do embrião (D8), totalizando 10 dias de tratamento. Além 
disso, foram realizadas duas infusões contendo 1,5 x 106 UI de Nistatina em dias alternados durante o cio, interrompendo o tratamento dois dias antes da ovulação. Como não foi possível recuperar embrião neste ciclo, foi realizada nova avaliação microbiológica no ciclo seguinte. Na segunda avaliação, constatou-se que o tratamento não surtiu efeito, já que foram observadas leveduras na citologia e novamente o agente patológico foi isolado. Para a determinação do percentual de inibição (PI) dos óleos frente à Candida sp., foi realizado teste de diluição em microplacas associado à leitura espectrofotométrica. Para o cálculo do PI, as leituras densitométricas das amostras com óleo foram comparadas com o crescimento na ausência deste e expressas na forma de percentual, considerando PI superior ou igual a 90\% como concentração inibitória mínima (CIM). Foram testadas as concentrações $10 ; 5 ; 2,5 ; 1,25 ; 0,625 ; 0,3125 ; 0,1562$ e $0 \mu \mathrm{L} / \mathrm{mL}$ de óleo. Ambos os óleos na concentração de $10 \mu \mathrm{L} / \mathrm{mL}$ foram efetivos no controle do agente, apresentando PI de $100 \%$. As demais concentrações demonstraram potencial inibitório, porém não foram suficientes para atingir a CIM. Caso fosse considerada a concentração inibitória média (CI50), todas as concentrações testadas de ambos os óleos seriam eficazes para o controle de pelo menos $50 \%$ do crescimento fúngico. Através destes resultados pôde-se concluir que o óleo de Alecrim e Capim Cidreira possuem propriedades antifúngicas, demonstrando potencial para o controle de fungos causadores da endometrite em éguas. No entanto, outras pesquisas estão sendo conduzidas para avaliação do efeito da aplicação in vivo destas substâncias.

Palavras-chave: Endometrite fúngica. Candida sp. Fitoterápicos. 